\title{
Effects of Corn Steep Liquor Supplementation on Voluntary Selection of Tallgrass Prairie Hay Contaminated with Sericea Lespedeza and Uncontaminated Tallgrass Prairie Hay
}

\author{
G.J. Eckerle, KC Olson, J.R. Jaeger, and L.A. Pacheco
}

\section{Introduction}

Sericea lespedeza (Lespedeza cuneata) is classified as a noxious weed throughout the Great Plains. It produces copious amounts of seed annually and contains high levels of condensed tannins during much of the growing season, which deters grazing by large domestic herbivores. In Kansas alone, this plant infests approximately 600,000 acres of native range, reducing native grass production by up to $92 \%$. Increased grazing pressure on sericea lespedeza by beef cattle may slow its spread and facilitate some measure of biological control. Feedstuffs or feed additives with tannin-binding properties may promote voluntary consumption of this plant by grazing beef cattle.

In previous studies, confined beef cattle fed polyethylene glycol daily ate more sericea lespedeza than cattle that were not fed polyethylene glycol; however, use of polyethylene glycol by commercial beef producers is problematic because feeding it at the rates necessary to increase intake of sericea lespedeza is cost-prohibitive and disallowed from a regulatory standpoint. We reported previously that low to moderate amounts of supplemental corn steep liquor (i.e., 0.6 to $1.8 \mathrm{~kg} /$ day) increased intake of tallgrass prairie hay contaminated with sericea lespedeza by beef cows fed in confinement. Corn steep liquor is an inexpensive, palatable, and abundant by-product of wet-corn milling and is generally regarded as safe (GRAS) by the U.S. Food and Drug Administration. Whether beef cattle supplemented with corn steep liquor will readily consume forage contaminated by sericea lespedeza when uncontaminated forage is available simultaneously is unknown. Therefore, the objective of our study was to determine the effects of low-level corn steep liquor supplementation on voluntary selection of tallgrass prairie hay contaminated by sericea lespedeza when uncontaminated tallgrass prairie hay was also available.

\section{Experimental Procedures}

Tallgrass prairie forage contaminated with sericea lespedeza was harvested from a single pasture in Greenwood County, KS, sun-cured, packaged in bales, and stored at the Kansas State University Commercial Cow-Calf Unit. Forage was harvested in late July, which corresponded to the budding stage of sericea lespedeza. Concentrations of condensed tannins in the plant are typically greatest at this stage of growth. Plantspecies composition on the study site was estimated using a modified step-point technique; sericea lespedeza comprised $19.3 \%$ of all plants encountered during the procedure. Aboveground biomass of sericea lespedeza averaged $893 \mathrm{lb} /$ acre.

Uncontaminated tallgrass prairie forage was harvested in Pottawatamie County, KS, also in late July. Species composition of contaminated and uncontaminated forage 
was similar in all respects, except for the presence of sericea lespedeza in the contaminated forage. Bales of each forage type were sampled to measure crude protein and acid detergent fiber concentration and paired based on similarity in those values. Average crude protein and acid detergent fiber concentrations in contaminated and uncontaminated hay are shown in Table 1. Purposeful selection for similarity in protein and fiber concentrations between forage types was intended to prevent confounding of differences in forage quality with effects on intake. Bales of contaminated and uncontaminated hay selected for the study were ground separately to a 4-inch particle size.

Corn steep liquor was purchased from Archer Daniels Midland in Columbus, NE, transported to the Kansas State University Commercial Cow-Calf Unit, and stored in a polyvinyl chloride container.

Sixteen mature beef cows (average initial weight $=1,022 \pm 153 \mathrm{lb}$; average initial body condition score $=4.2 \pm 0.8[1=$ thin, $9=$ very fat $]$ ) were used in the study. Cows were housed in individual pens and were fed individually using a Calan gate system (American Calan, Northwood, NH). Cows were stratified by body weight and body condition score and were assigned randomly to be supplemented with 0 or $1.32 \mathrm{lb} /$ day of corn steep liquor (dry basis; equivalent to 0 or $3 \mathrm{lb} /$ day as-fed).

Cows were individually confined in $5 \times 20 \mathrm{ft}$ pens and offered uncontaminated hay and contaminated hay in separate feed bunks free choice. Access to both contaminated and uncontaminated tallgrass prairie hay was simultaneous and allowed cows the opportunity to display preference for one forage type over the other.

Supplemental corn steep liquor was offered to treated cows for a period of 24 days; it was consumed completely within 30 minutes. Forages were fed twice daily during that period at 6:00 a.m. and 6:00 p.m. Daily forage refusals were collected and weighed at 5:30 a.m. Daily voluntary dry matter intakes of contaminated and uncontaminated tallgrass prairie forage were determined by subtracting daily refusals from the total amount of hay offered. Intakes were expressed as a percentage of initial cow body weight. Totaltract diet digestion was assessed on days 18 through 24. Forage samples were collected on days 18 through 23. Fecal grab samples were collected every 4 hours on days 19 through 24 . The collection interval was staggered 2 hours each day to account for diurnal variation in fecal output and composition.

\section{Results and Discussion}

Uncontaminated hay dry matter intake was not different $(P=0.65)$ between supplemented and unsupplemented cows (Table 2). Conversely, cows supplemented with corn steep liquor ate $25 \%$ more $(P<0.01)$ sericea lespedeza-contaminated forage than unsupplemented cows. Cows supplemented with corn steep liquor also ate more $(P=0.05)$ total forage dry matter than unsupplemented cows.

Beef cows supplemented with corn steep liquor voluntarily consumed more tallgrass prairie hay contaminated with sericea lespedeza than unsupplemented beef cows, even when uncontaminated hay was available concurrently. These data were interpreted to indicate that low levels of supplemental corn steep liquor may increase beef cow acceptance of and tolerance for high-tannin forages. 
Total-tract dry matter and crude protein digestibilities did not differ $(P \geq 0.17)$ between treatments. We previously reported that total-tract dry matter and crude protein digestibilities by beef cows fed tallgrass prairie hay contaminated with sericea lespedeza were maximized at corn steep liquor supplementation levels of $2.68 \mathrm{lb} /$ day (dry basis) or greater. Further research is warranted to evaluate feeding rates of corn steep liquor necessary for optimal digestion of low-quality tallgrass prairie hay contaminated with sericea lespedeza.

Total digestible dry matter intake by cows fed corn steep liquor was $23 \%$ greater $(P<0.01)$ than that by unsupplemented cows. We previously reported that unadapted cattle fed 2.68 to $4.03 \mathrm{lb} /$ day (dry basis) of corn steep liquor had comparable total digestible dry matter intake. Cows supplemented with corn steep liquor in our study appeared to have greater dietary energy availability than unsupplemented cows, even though the estimated increase in $\mathrm{NE}_{\mathrm{m}}$ supply associated with supplementing corn steep liquor at $1.32 \mathrm{lb} /$ day was only $1.1 \mathrm{Mcal} /$ day. Over a longer feeding period, this may have translated to improved performance.

\section{Implications}

Low-level supplementation of corn steep liquor may increase both acceptance of and tolerance for high tannin-forages by beef cows. Corn steep liquor fed at $1.32 \mathrm{lb} / \mathrm{day}$ ameliorated some of the negative consequences of tannin consumption on digestible dry matter intake. In addition, voluntary consumption of high-tannin forage increased by $25 \%$ in supplemented compared with unsupplemented beef cows. Whether supplemental corn steep liquor can promote voluntary selection of actively growing sericea lespedeza by beef cattle grazing native rangeland in the Kansas Flint Hills remains unknown. 
Table 1. Chemical composition (dry matter basis) of corn steep liquor, tallgrass prairie hay, and tallgrass prairie hay contaminated with sericea lespedeza

\begin{tabular}{lccc}
\hline Item, \% & Corn steep liquor & $\begin{array}{c}\text { Uncontaminated } \\
\text { forage }\end{array}$ & $\begin{array}{c}\text { Contaminated } \\
\text { forage }\end{array}$ \\
\hline Dry matter & 45.1 & 93.1 & 92.6 \\
Organic matter & 95.1 & 87.0 & 86.0 \\
Crude protein & 31.6 & 4.1 & 4.1 \\
Acid detergent fiber & - & 40.8 & 40.2 \\
Neutral detergent fiber & 0.5 & 65.2 & 65.3 \\
Calcium & 0.04 & 0.27 & 0.31 \\
Phosphorus & 0.63 & 0.08 & 0.08 \\
\hline
\end{tabular}

Table 2. Effects of low-level corn steep liquor supplementation on forage intake and digestion by beef cows simultaneously offered tallgrass prairie hay that was contaminated with sericea lespedeza and uncontaminated by sericea lespedeza ${ }^{a}$

\begin{tabular}{|c|c|c|c|c|}
\hline \multirow[b]{2}{*}{ Item } & \multicolumn{2}{|c|}{$\begin{array}{l}\text { Corn steep liquor, } \\
\text { lb/day (dry basis) }\end{array}$} & \multirow[b]{2}{*}{ SEM } & \multirow[b]{2}{*}{$P$-value } \\
\hline & 0 & 1.32 & & \\
\hline \multicolumn{5}{|c|}{ Dry matter intake, \% of body weight } \\
\hline Uncontaminated forage & 0.91 & 0.87 & 0.066 & 0.65 \\
\hline Contaminated forage & 1.06 & 1.33 & 0.055 & $<0.01$ \\
\hline Total forage & 1.97 & 2.20 & 0.086 & 0.05 \\
\hline Digestible dry matter & 1.97 & 2.35 & 0.087 & $<0.01$ \\
\hline \multicolumn{5}{|l|}{ Total-tract digestibility, $\%$} \\
\hline Dry matter & 50.5 & 53.9 & 1.66 & 0.17 \\
\hline Crude protein & 17.1 & 18.5 & 2.15 & 0.64 \\
\hline
\end{tabular}

